\title{
PENGARUH PENERAPAN METODE PROYEK TERHADAP PERKEMBANGAN KEMAMPUAN BERSOSIALISASI PADA ANAK USIA 5-6 TAHUN
}

(Studi Eksperimen Lemah Terhadap Anak Usia 5 - 6 Tahun Kelompok B1 di TK Bina Nusantara Desa Naluk Kecamatan Cimalaka Kabupaten Sumedang )

\author{
Hj. Tin Rustini ${ }^{1}$ \\ Rohayati $^{2}$
}

\begin{abstract}
ABSTRAK
Penelitian ini dilatarbelakangi oleh hasil temuan penulis bahwa sebagian besar anak TK Bina Nusantara Desa Naluk Kecamatan Cimalaka Kabupaten Sumedang kurang berrminat dalam mengikuti kegiatan pembelajaran secara berkelompok, salah satu penyebabnya adalah guru kurang menggunakan metode yang tepat, guru kurang melibatkan anak -anak dalam bersosialisasi dengan anggota kelompoknya /temannya.

Penelitian ini menggunakan "One group pretest postest design” .Adapun sampel penelitian ini adalah satu kelompok (kelas eksperimen) dikenai 3 perlakuan dari siswa kelas B1sejumlah 14 orang terdiri dari 7 orang laki-laki dan 7 orang perempuan. Hasil penelitian menunjukkan kemampuan bersosialisasi siswa kurang sebelum menggunakan metode proyek menggunakan metode klasikal dengan metode proyek denagn tiga kali perlakuan semakin berkembang. Terdapat perbedan yang signifikan terhadap kemampuan bersosilisasi anak usia $5-6$ tahun sebelum dan setelah 3 kali perlakuan dengan menggunakan metode proyek sangat berpengaruh secara signifikan terhadap kemampuan bersosialisasi pada anak usia 5-6 tahun di TK Bina Nusantara Desa Naluk Kecamatan Cimalaka Kabupaten Sumedang.

Kata kunci : Metode Proyek- Kemampuan bersosialisasi anak 5-6 tahun
\end{abstract}

\section{A. PENDAHULUAN}

Pendidikan bagi anak usia dini merupakan suatu hal yang sangat penting karena masa usia dini merupakan masa yang sangat fundamental, di mana masa usia dini merupakan masa terbentuknya fondasi dan dasar kepribadian yang akan menentukan pengalaman anak selanjutnya. Pengalaman yang dialami anak pada usia dini akan berpengaruh kuat terhadap kehidupan selanjutnya. Pengalaman tersebut akan bertahan lama bahkan tidak terhapuskan. Oleh karena itu diperlukan pendidikan dan pelayanan yang tepat bagi anak usia dini.

Pada dasarnya pendidikan anak usia dini merupakan salah satu bentuk penyelenggaraan pendidikan yang menitikberatkan pada peletakan dasar ke arah pertumbuhan dan perkembangan fisik (koordinasi motorik halus dan kasar), kecerdasan (daya pikir, daya cipta, kecerdasan emosi, kecerdasan spiritual), sosio emosional (sikap dan perilaku serta agama), bahasa dan komunikasi sesuai dengan keunikan dan tahap-tahap perkembangan yang dilalui oleh anak usia dini(dalam Nugraha dkk 2009:3.3).

Sejalan dengan tahap pertumbuhan dan perkembangan anak yang selanjutnya akan menjadi orang dewasa, anak akan mengenal lingkungan luas

\footnotetext{
${ }^{1}$ Dosen PGPAUD UPI Kampus Cibiru

${ }^{2}$ Alumni PGPAUD UPI Kampus Cibiru
} 
kemudian bermasyarakat atau berkehidupan sosial. Agar anak dapat diterima di lingkungan luar, anak harus memiliki keterampilan bersosial atau berinteraksi dengan orang lain. Menurut Yusuf (2007:122) "Perkembangan sosial merupakan pencapaian kematangan dalam hubungan sosial”. Perkembangan sosial dapat pula diartikan sebagai proses belajar untuk menyesuaikan diri terhadap norma-norma kelompok, moral dan tradisi: meleburkan diri menjadi satu kesatuan dan saling berkomunikasi dan kerja sama. Pada awal manusia dilahirkan belum bersifat sosial, dalam artian belum memiliki kemampuan dalam berinteraksi dengan orang lain.

Menurut Dimyati dan Mujiono (2006:88) "Manusia adalah mahluk sosial, perilakunya tidak hanya terpengaruh oleh faktor biologis saja, tetapi faktor-faktor sosial. Perilaku manusia terpengaruh oleh tiga komponen penting yaitu afektif (aspek sosial-emosional), kognitif (aspek intelektual) dan konatif (kemauan dan kebiasaan bertindak)". Maka dari itu keterampilan bersosialisasi sudah harus ditanamkan pada anak sejak usia dini sesuai dengan tingkat perkembangannya yang masih memerlukan suasana bermain, maka guru PAUD, dalam memberikan atau mengajarkan keterampilan bersosialisasi haruslah memilih metode atau teknik yang menarik bagi anak.

Merujuk pada tujuan pendidikan itu sendiri, berprilaku sosial perlu dimiliki anak masih kecil sebagai suatu fundasi bagi perkembangan kemampuan anak berinteraksi dengan lingkungannya secara lebih luas. Sejalan dengan perkembangan fisiknya, anak usia sekitar 5-6 tahun semakin berminat pada teman-temannya. Ia mulai menunjukkan hubungan dan kemampuan bekerjasama yang lebih intens dengan teman-temanya. Anak memilih teman berdasarkan kesamaan aktivitas dan kesenangan, serta kenginan yang kuat untuk dapat diterima dalam kelompoknya. Pengalaman berhubungan (bersosialisasi) dengan orang lain semakin banyak pula hal yang dapat dipelajarinya, ini menjadi bekal dalam meningkatkan keterampilan sosialisasi tersebut. Melalui pergaulan dan aktivitas sosialnya, minat dan motivasi untuk bergaul akan memberi peluang yang lebih besar kepada pembentukkan perilaku anak.

Pertimbangan psikologis berangkat dari asumsi bahwa bersosialisasi harus diajarkan kepada para siswa sesuai dengan metode dan strategi tertentu, sehingga belajar bersosialisasi dalam hal ini belajar berkelompok menjadi suatu aktifitas yang menyenangkan dan menarik bagi siswa. Strategi untuk menciptakan proses pembelajaran meningkatkam kemampuan anak bersosialisasi yang menarik dan menyenangkan bagi siswa bisa dilaksanakan dengan optimal jika guru banyak memahami aspek-aspek psikologis siswa dalam belajar bersosialisasi.

Berdasarkan analisis masalah yang dilakukan oleh penulis pada anak usia 5-6 tahun di TK Bina Nusantara Desa Naluk Kecamatan Cimalaka Kabupaten Sumedang, ditemukan masalah yang terjadi pada saat kegiatan pembelajaran di kelompok B1 dimana sebagian anak kurang berminat dalam megikuti kegiatan pembelajaran kelompok. Salah satu penyebabnya adalah metode pembelajaran yang digunakan dalam kegiatan kelompok tesebut kurang tepat sehingga anak tidak mempunyai minat dan kurang termotivasi dalam kegiatan.Penyebab lainnya adalah guru kurang mempraktekkan atau melibatkan anak dalam kegiatan bersosialisasi dengan teman. 
Selain penyebab yang telah ditulis di atas, ada hal lain yang perlu dipahami oleh guru yaitu perbedaan karakteristik setiap anak. Perbedaan karakteristik tersebut memnyebabkan kemampuan anak dalam bersosialisasi akan berbeda. Oleh sebab itu, berdasarkan uraian diatas peneliti tertarik untuk menguji kembali dan akan mencoba menganalisis tentang pengaruh penggunaan metode proyek terhadap perkembangan bersosialisasi pada anak usia 5-6 tahun di TK Bina Nusantara Desa Naluk Kecamatan Cimalaka Kabupaten Sumedang tempat penulis bertugas.

Alasan mengapa penulis memilih metode proyek untuk mengembangkan kemampuan bersosialisasi pada anak usia 5-6 tahun adalah karena semua anak pasti senang dengan suatu proyek langsung dalam kegiatan menyelesaikan suatu pekerjaan secara bersama-sama. Pembelajaran dengan menggunakan metode proyek diharapkan akan mengatasi kesulitan belajar anak dalam bersosialisasi dengan teman dan lingkungan sekitar, sehingga anak akan memperoleh pengalaman belajar yang menghadapkan anak dengan persoalan sehari-hari yang harus dipecahkan secara berkelompok. Metode proyek menjadi wahana untuk menggerakkan kemampuan kerjasama dengan sepenuh hati, meningkatkan keterampilan dalam berhubungan dengan orang lain yang merupakan kemampuan bersosialisasi anak.

Dewasa ini berbagai model pembelajaran dan metode sudah banyak dikenalkan di kalangan pendidik. Guru juga dituntut untuk selalu berinovasi dalam mengajarkan materi kepada peserta didiknya. Inovasi di sini meliputi model, metode dan pemanfaatan media pembelajaran. Dalam pembelajaran peranan metode atau strategi pembelajaran sangat diperlukan agar siswa tidak verbalisme.

Berdasarkan permasalahan di atas, secara jelasnya permasalahan tersebut dibuat ke dalam sebuah penelitian yang berjudul Pengaruh Penerapan Metode Proyek Terhadap Perkembangan Kemampuan Bersosialisasi pada Anak Usia 5-6 Tahun, dengan menggunakan metode penelitian studi eksperimen lemah terhadap kelompok B1 di TK Bina Nusantara Desa Naluk Kecamatan Cimalaka Kabupaten Sumedang.

Melalui berbagai pertimbangan, baik secara teoritis maupun menurut pengamatan yang terjadi di lapangan secara langsung, penulis dapat menemukan beberapa permasalahan yang timbul diantaranya:

1. Bagaimana kemampuan bersosialisasi anak usia 5-6 tahun sebelum dan sesudah penerapan metode proyek di TK Bina Nusantara Cimalaka?

2. Apakah terdapat perbedaan kemampuan bersosialisasi anak usia 5-6 tahun sebelum menggunakan metode proyek dengan sesudah menggunakan metode proyek di TK Bina Nusantara Cimalaka?

Tujuan yang ingin dicapai oleh penulis dalam penelitian yang dilakukan terhadap anak yang memiliki kesulitan dalam kegiatan pembelajaran yang melibatkan interaksi dengan teman-teman, yaitu sebagai berikut.

1. Untuk mengetahui bagaimana kemampuan bersosialisasi anak usia 5-6 tahun sebelum dan sesudah penerapan metode proyek di TK Bina Nusantara Cimalaka. 
2. Untuk mengetahui apakah terdapat perbedaan kemampuan bersosialisasi anak usia 5-6 tahun sebelum menggunakan metode proyek dengan sesudah menggunakan metode proyek di TK Bina Nusantara Cimalaka.

\section{B. TINJAUAN TEORITIS}

\section{Metode Proyek}

Menurut Moeslichatoen (2004:137) "Metode proyek merupakan salah satu cara pemberian pengalaman belajar dengan menghadapkan anak dengan persoalan sehari-hari yang harus dipecahkan secara berkelompok”. Metode proyek berasal dari gagasan John Dewey tentang konsep “learnig by doing” yakni 'Proses perolehan hasil belajar dengan mengerjakan tindakan-tindakan tertentu sesuai dengan tujuannya, terutama proses penguasaan anak tentang bagaimana melakukan sesuatu pekerjaan yang terdiri atas serangkaian tingkah laku untuk mencapai tujuan'. Peran guru sebagai fasilitator dalam pelaksanaan pendidikan untuk anak usia dini harus mampu memberikan kemudahan kepada anak untuk mempelajari berbagai hal yang yang terdapat dalam lingkungannya. Metode proyek merupakan strategi pengajaran yang melibatkan anak dalam belajar memecahkan masalah dengan melakukan kerjasama dengan anak lain, masingmasing melakukan bagianpekerjaannya secara individual atau dalam kelompok kecil untuk mencapai tujuan yang menjadi milik bersama.Gagasan ini dikembangkan oleh William H.Kilpatrich dalam metode proyek. Metode proyek merupakan 'Salah satu cara pemecahan masalah yang diterapkan secara luas daalm setiap pemecahan masalah yang dialami dalam kehidupan sehari-hari' (Bossing, Moeslichatoen 2004:139).

Metode proyek menjadi penting untuk diterapkan pada anak usia dini karena berkaitan dengan kehidupan sehari-hari secara nyata sehingga anak belajar dari pengalamannya sendiri. Hal ini terbukti lebih bermakna dibandingkan metode biasa. Selain itu anak dapat belajar mengatur diri sendiri untuk bekerja sama dengan temandalam memmecahkan masalah dan dapat berdampak dalam pengembangan etos kerja.

Berdasarkan uraian di atas, jelaslah bahwa metode proyek merupakan metode pembelajaran aktif dimana anak diberi kebebasan dalam memilih kegiatan, sehingga dapat disimpulkann bahwa metode proyek itu suatu metode mengajar yang bahan ajarnya diorganisasikan sedemikian rupa, serta mengandung suatu pokok masalah dan memberikan kesempatan pada anak-anak untuk bersosialisasi dan bekerja sama dengan kelompoknya yang harus dipecahkan baik secara individu maupun berkelompok, sehingga metode proyek dalam penelitian ini dipandang dapat diterapkan dalam mengembangkan kemampuan bersosialisasi anak usia 5-6 tahun di Taman Kanak-kanak.

Karakteristik dari metode proyek itu adalah memiliki kebebasan yang tinggi dimana anak memilih topik dan anak mencari bahan sehingga konsekuensi yang timbul adalah anak akan memiliki motivasi yang tinggi untuk menyelesaikan pekerjaan. "Metode proyek dapat digunakan dalam pembelajaran aktif karena anak bertindak sebagai subjek belajar yang memiliki kebebasan memilih dan guru lebih bersifat sebagai fasilitator dalam pembelajaran” (Masitoh, dkk 2005:201). 
Ada tiga tahap dalam merancang kegiatan proyek bagi anak di Taman Kanak-kanak yaitu: merancang persiapan yang dilakukan guru, merancang pelaksanaan kegiatan proyek bagi anak, dan merancang penilaian kegiatan proyek bagi anak (Moeslichatoen 2004:145).

\section{Kemampuan Bersosialisasi}

Kemampuan bersosialisasi atau disebut juga sebagai kecerdasan interpersonal menurut Lwin, dkk (2008:197) adalah "Kemampuan untuk berhubungan dengan orang-orang di sekitar kita”. Kecerdasan ini adalah kemampuan untuk memahami dan memperkirakan perasaan, temperamen, suasana hati, maksud dan keinginan orang lain dan menanggapinya secara layak. Kecerdasan inilah yang memungkinkan kita untuk membangun hubungan dengan masyarakat. Kecerdasan interpersonal harus dibina selama tahap pendewasaan. kecerdasan interpersonal bukan sesuatu yang dilahirkan bersama anak tetapi sesuatu yang harus dikembangkan melalui pembinaan dan pengajaran seperti kecerdasan lainnya.

Kemampuan bersosialisasi merupakan cara anak dalam melakukan interaksi baik dalam hal bertingkah laku maupun dalam hal berkomunikasi dengan orang lain. Kebanyakan anak merasa kesulitan dalam berinteraksi dengan teman, guru maupun orang yang baru dikenalnya. Anak akan baik perkembangan keterampilan sosialnya apabila pola asuhnya baik pula yang diberikan oleh orangtuanya.Kemampuan bersosialiasi juga diartikan mampu menyesuaikan diri dengan tuntutan yang ada dilingkungannya agar terhindar dari berbagai masalah dalam berinteraksi dengan temannya, serta mampu menghindari konflik dengan sesamanya saat berkomunikasi secara fisik(tatap muka) ataupun secara verbal(bahasa).Berkat kemampuan bersosialisasi anak dapat menyesuaikan dirinya dengan kelompok teman sebaya maupun dengan lingkungan masyarakat sekitar.

Kemampuan berosialisasi/kecerdasan interpersonal menekankan pada kemampuan anak untuk memahami orang lain dengan segenap perbedaan motivasi, kehendak, dan suasana hati. Kecerdasan interpersonal memberikan keterampilan pada seseorang untuk bekerja sama dengan orang lain. Kecerdasaan ini digunakan untuk berkomunikasi, saling memahami, dan berinteraksi dengan orang lain. Lwin, dkk (2008:198) mengatakan "Penyebab utama rendahnya kecerdasan interpersonal adalah karena ketika anak masih kecil kurang diajarkannya bagaimana berhubungan dengan orang lain atau kesempatan untuk berbaur”. Pentingnya mengembangkan kecerdasan interpersonal bagi anak adalah untuk menjadi orang dewasa yang sadar secara sosial dan mudah menyesuaikan diri, menjadi berhasil dalam pekerjaan, demi kesejahteraan emosional dan fisik.

Lwin, dkk (2008:205) menjelaskan gambaran mengenai indikator kecerdasaan interpersonal. Tanda-tanda anak dengan kecerdasan interpersonal yang tinggi, diungkapkan Lwin, dkk (2008: 205) sebagai berikut.

a. Berteman dan berkenalan dengan mudah.

b. Suka berada di sekitar orang lain.

c. Ingin tahu mengenai orang lain dan ramah terhadap orang asing. 
d. Menggunakan bersama mainannya dan berbagi permen dengan temantemannya.

e. Mengalah pada anak-anak lain.

f. Mengetahui bagaimana menunggu gilirannya selama bermain.

\section{METODOLOGI PENELITIAN}

\section{Subyek Penelitian}

Lokasi penelitian dilaksanakan di TK Bina Nusantara yang berada di Jalan Pemuda No. 47 Desa Naluk Kecamatan Cimalaka Kabupaten Sumedang. Populasi dari penelitian ini adalah siswa dari TK Bina Nusantara kecamatan Cimalaka kabupaten Sumedang yang berjumlah 25 orang yang dibagi kedalam 2 kelas yaitu kelompok B1 sebanyak 14 orang dan kelompok B2 sebanyak 11 orang.Sampel dari penelitian ini adalah siswa dari kelompok B1 yang berjumlah 14 orang yang terdiri dari 7 orang siswa perempuan dan 7 orang siswa laki-laki.

\section{Metode dan Desain Penelitian}

Metode penelitian yang dilakukan adalah metode penelitian kuantitatif yang dapat diartikan sebagai metode penelitian yang berlandaskan pada filsafat positivistik, untuk meneliti populasi dan sampel tertentu melalui teknik sampling, penggunaan instrumen dan analisis data bersifat kuantitatif dengan tujuan untuk menguji hipotesis.

Desain penelitian ini menggunakan “One Group Pretest-Posttest Design” maksudnya penelitian ini dilakukan dengan membandingkan hasil pretes dan posttest pasca perlakuan.Satu kelompok (kelas eksperimen) dikenai satu perlakuan tertentu. Desain penelitian ini dapat digambarkan sebagai berikut:

\begin{tabular}{|c|c|c|c|}
\hline Kelas & Pre Test & Treatment & Pos Test \\
\hline Eksperimen & O1 & $\mathrm{X}$ & O2 \\
\hline
\end{tabular}

(Sugiyono, 2010:75)

keterangan:

$\mathrm{O} 1$ = Nilai Pre Test (sebelum diberi perlakuan)

$\mathrm{X}=$ Treatment (Perlakuan)

$\mathrm{O} 2$ = Nilai Post Test (setelah diberi perlakuan)

Penerapan desain ini sederhana, peneliti cukup melaksanakan pretes sebelum pembelajaran dimulai dan kemudian melaksakan postes setelah pembelajaran selesai. Hasil dari pretes dan postes selanjutnya peneliti akan membandingkan untuk mengetahui ada atau tidaknya perbedaan sebelum dan sesudah perlakuan.

\section{HASIL PENELITIAN DAN PEMBAHASAN}

Berdasarkan hasil analisis data di atas dapat dikemukakan bahwa metode proyek berpengaruh secara signifikan terhadap peningkatan kempuan bersosialisasi anak di Taman Kanak-kanak. Hal ini terbukti dari pengolahan data pretest perlakuan 1 pada kemampuan bersosialisasi anak didapatkan nilai mean adalah 10,3571 varian 3.170 dan standar deviasi sebesar 1.78054. Sedangkan dari hasil pengolahan data nilai posttest perlakuan 3 di dapatkan nilai mean 13.5714 varian 4.264 dan standar deviasinya adalah 2.06488 . 
Pengujian yang dilakukan adalah uji t (T-Test Sampel Independent) dengan asumsi data berasal dari populasi yang berdistribusi normal.Diketahui bahwa nilai t signifikansi adalah -4,411 dengan asumsi kedua kelompok berasal dari populasi yang berdistribusi normal (Asymp.Sig) adalah 0,000. Nilai signifikansi ini lebih kecil dari 0,05, sehingga berdasarkan kriteria pengambilan keputusan di atas, Ho ditolak sehingga didapat hasil bahwa purata (mean) populasi yang tidak sama. Sehingga dapat disimpulkan bahwa purata (mean) nilai posttest lebih baik dari pada nilai prestest. Dengan kata lain purata (mean) siswa yang telah menggunakan metode proyek terhadap kemampuan bersosialisasi di Taman Kanak-kanak Bina Nusantara kelompok B1 lebih baik dibanding sebelum menggunakan metode proyek.

Adanya perbedaan pada pretest perlakuan 1 dan posttest perlakuan 3 ini disebabkan oleh metode yang digunakan guru dalam proses pembelajaran. Pada perlakuan 1 yang menggunakan treatment berupa kegiatan proyek menghias rumah adat, anak-anak begitu bersemangat dan antusias dalam kegiatan, anakanak terlibat dalam kegiatan kelompok, anak-anak biasa berkomunikasi dengan teman dalam kelompoknya, anak-anak mampu menyelesaikan tugasnya baik itu yang mandiri atau tugas yang kelompok dalam hal ini mereka sudah bisa menunjukkan tanggung jawab terhadap tugas yang diberikan oleh guru, dan anakanak mampu menjawab pertanyaan dari guru sesuai yang diharapkan. Meskipun dari 14 orang anak masih terdapat 3 orang anak yang belum mencapai perkembangan yang maksimal sesuai indikator-indikator yang telah ditentukan. Sedangkan pada perlakuan 3 yang menggunakan treatment berupa kegiatan proyek mempersiapkan pesta ulang tahun sudah dapat terlihat anak-anak begitu gembira dan semangat pada saat guru mengumumkan kegiatan yang akan dilaksanakan adalah mempersiapkan ulang tahun. Anak begitu termotivasi dalam kegiatan sehingga nilai yang diperoleh anak terhadap empat indikator yang dinilai yaitu dapat mengajak teman untuk bermain/belajar, dapat melaksanakan kelompok, dapat melaksanakan tugas sendiri sampai selesai dan dapat menunjukkan kebanggaan terhadap hasil karyanya sudah menunjukkan peningkatan dibandingkan pada saat pretest perlakuan 1. Aspek-aspek yang di observasi dalam aktivitas anak selama pelaksanaan proyek pada perlakuan 3 lebih banyak menunjukan peningkatan, seperti halnya anak dengan penuh semangat terlibat dalam proyek mempersiapkan ulang tahun, sebagian besar anak sudah mampu menyelesaikan tanggung jawabnya secara tuntas dalam proyek, anak-anak sudah mampu mengerjakan tugas mandiri secara kreatif dalam proyek dan anak dapat menyelesaikan bagian pekerjaan bersama anak lain dalam proyek.

Perbedaan nilai yang diperoleh dalam ke tiga perlakuan yang diberikan dalam penelitian ini selama mengunakan metode proyek terhadap kemampuan bersosialisasi anak dapat dilihat dari perolehan nilai rata-rata pada tiap perlakuan yang diberikan, rata-rata nilainya semakin meningkat dari tiap tahap tes yang dilakukan, sehingga dapat dengan jelas terlihat bahwa pembelajaran kelompok dengan menggunakan metode proyek sangat berpengaruh secara signifikan terhadap perkembangan kemampuan bersosialisasi pada anak usia 5-6 tahun di TK Bina Nusantara Desa Naluk Kesamatan Cimalaka Kabupaten Sumedang. 
Ditinjau dari esensi sosialisasi dalam Hurlock ( 2007 : 251) anak akan belajar bersosialisasi hanya apabila mereka mempunyai motivasi untuk melakukannya. Motivasi sebagian besar bergantung pada tingkat kepuasan yang dapat diberikan oleh aktivitas sosial yang diberikan kepada anak. Jika mereka memperoleh kesenangan melalui hubungan dengan orang lain, maka mereka akan mengulanginya, jika hubungan sosial hanya memberikan kegembiraan yang sedikit, mereka akan menghindarinya apabila mungkin. Kemampuan berosialisasi/kecerdasan interpersonal menekankan pada kemampuan anak untuk memahami orang lain dengan segenap perbedaan motivasi, kehendak, dan suasana hati. Kecerdasan interpersonal memberikan keterampilan pada seseorang untuk bekerja sama dengan orang lain. Kecerdasaan ini digunakan untuk berkomunikasi, saling memahami, dan berinteraksi dengan orang lain.

Sebagaimana dikemukakan pada bagian tinjauan pustaka, metode proyek mampu meningkatkan kemampuan bersosialisasi anak. Hal ini sejalan dengan pendapat Dalam penggunaannya metode proyek Bahri dan Zain (2006:83) yang mengemukakan kelebihan penerapan metode proyek dalam pembelajaran, diantaranya:

1. Dapat memperluas pemikiran siswa yang berguna dalam menghadapi masalah kehidupan.

2. Dapat membina siswa dengan kebiasaan menerapkan pengetahuan, sikap, dan keterampilan dalam kehidupan sehari-hari secara terpadu.

3. Metode ini sesuai dengan prinsip-prinsip didaktik modern yang dalam pengajaran perlu diperhatikan:

a. Kemampuan individual siswa dan kerjasama dalam kelompok.

b. Bahan pelajaran tidak terlepas dari kehidupan riil sehari-hari yang penuh dengan masalah.

c. Pengembangan aktivitas, kreativitas dan pengalaman siswa banyak dilakukan.

d. Agar teori dan praktik, sekolah dan kehidupan masyarakat menjadi satu kesatuan yang tak terpisahkan.

Selain pendapat di atas, Yamin (2010 : 166) menambahkan bahwa metode proyek adalah salah satu metode yang digunakan untuk melatih kemampuan anak memecahkan masalah yang dialami dalam kehidupan sehari-hari. Cara ini dapat menggerakkan anak untuk melakukan kerjasama sepenuh hati, secara terpadu untuk tujuan bersama.

Metode proyek menjadi penting untuk diterapkan pada anak usia dini karena berkaitan dengan kehidupan sehari-hari secara nyata sehingga anak belajar dari pengalamannya sendiri. Hal ini terbukti lebih bermakna dibanding dengan metode biasa. Selain itu, anak pun dapat belajar mengatur diri sendiri untuk bekerjasama dengan teman dalam memecahkan masalah dan dapat berdampak dalam mengembangkan etos kerja melalui keterlibatan langsung/berpengalaman dalam kegiatan, hal ini sejalan dengan yang di ungkapkan oleh Dale ( Dimyati dan Mudjiono, 2006 : 45) yang menyatakan bahwa "Belajar yang lebih baik adalah belajar melalui pengalaman langsung." Dalam belajar melalui pengalaman langsung siswa tidak sekedar mengamati secara langsung tetapi ia harus menghayati, terlibat langsung dalam perbuatan, dan bertanggung jawab terhadap 
hasilnya. Pentingnya keterlibatan langsung dalam belajar dikemukakan oleh John Dewey dengan "lerning by doing”. Belajar sebaiknya dialami melalui perbuatan langsung. Belajar harus dilakukan oleh siswa secara aktif, baik individual maupun kelompok, dengan cara memecahkan masalah (problem solving). Guru bertindak sebagai pembimbing dan fasilitator.

Sebagai fasilitator, guru berperan dalam memberikan pelayanan untuk memudahkan siswa dalam kegiatan proses pembelajaran dengan tujuan mempermudah siswa belajar. Guru dituntut mempunyai keterampilan dalam merancang suatu metode pembelajaran dan mampu memanfaatkan berbagai media sebagai sumber belajar.

Keterlibatan anak (siswa) di dalam belajar jangan diartikan keterlibatan fisik semata, namun lebih dari itu terutama adalah keterlibatan mental sosialemosional, keterlibatan dengan kegiatan kognitif dan pencapaian dan perolehan pengetahuan, dalam penghayatan dan internalisasi nilai-nilai dalam pembentukan sikap dan nilai, dan juga pada saat mengadakan latihan-latihan pembentukan keterampilan (kreativitas).

Pembelajaran dengan menggunakan metode proyek memang sangat mendukung kemampuan anak dalam konteks sosial dengan teman pada saat pembelajaran, lain hal dengan pembelajaran yang kurang memperhatikan metode dalam penyampaiannya dapat menyebabkan anak kurang termotivasi dan anak kurang bersemangat dalam kegiatan anak cenderung dipaksakan untuk mengikuti kegiatan dan hal ini membuat anak tidak akan memperoleh ilmu sesuai tahap perkembangannya secara optimal yang dapat menyebabkan kehilangan masa keemasan anak sebagai pribadi yang mempunyai karakter unik. Belajar tidak dapat dipaksakan oleh orang lain dan juga tidak dapat dilimpahkan kepada orang lain, belajar hanya mungkin terjadi apabila anak aktif mengalami sendiri. Hal ini sesuai dengan yang dikemukakan oleh John Dewey (Dimyati dan Mudjiono 2006 :31) "Bahwa belajar adalah menyangkut apa yang harus dikerjakan anak (siswa) untuk dirinya sendiri, maka inisiatif harus datang dari siswa sendiri, guru hanya sekedar pembimbing dan pengarah.

Berdasarkan berbagai uraian di atas, dapat dikemukakan bahwa metode proyek mampu meningkatkan kemampuan bersosialisasi anak dengan baik.Anakanak lebih tertarik, bersemangat dan termotivasi dalam kegiatan pembelajaran dengan metode proyek. Proses pembelajaran akan berhasil manakala siswa mempunyai motivasi dalam belajar, oleh sebab itu guru perlu menumbuhkan motivasi belajar siswa. Hilgard (dalam Sanjaya 2006 : 29) mengatakan bahwa "Motivasi adalah suatu keadaan yang terdapat dalam diri seseorang yang menyebabkan seseorang melakukan kegiatan tertentu untuk mencapai tujuan”.

Anak lebih terpicu untuk mengungkapkan pendapat, bekerjasama, dan mencari dan mengumpulkan informasi dari berbagai sumber. Disisi lain guru juga lebih kreatif menciptakan kegiatan pembelajaran supaya tidak ,membosankan dan lebih bermakna bagi anak, selain itu kemampuan guru dalam menyampaikan pembelajaran juga lebih baik. Oleh karena itu guru sebagai ujung tombak dalam setiap kegiatan yang akan dilaksanakan oleh anak, sekaligus sebagai penentu ketercapaian tujuan pembelajaran di kelas sangat perlu memperhatikan hal-hal tersebut diatas. Dengan demikian maka dapat dipastikan bahwa peranan guru dan 
metode sama-sama penting dalam mengembangkan setiap aspek perkembangan yang ada pada anak.

\section{E. KESIMPULAN DAN SARAN}

Berdasarkan temuan dari hasil analisis yang dilakukan oleh penulis tentang Penerapan Metode Proyek Dalam Meningkatkan Kemampuan Bersosialisasi Anak Usia 5-6 Tahun yang di laksanakan di TK Bina Nusantara Desa Naluk Kecamatan Cimalaka Kabupaten Sumedang diperoleh kesimpulan sebagai berikut.

1. Kemampuan anak dalam bersosialisasi terutama di dalam kegiatan kelompok di kelas B1 sebelum menggunakan metode proyek masih belum berkembang dengan baik hal itu dikarenakan cara pembelajaran dalam mengembangkan kemampuan bersosialisasi ini kurang menggunakan metode yang tepat. Pembelajaran kelompok hanya dilakukan secara klasikal dan kegiatan yang dirancang guru pun kurang menarik minat anak sehingga anak kurang termotivasi untuk aktif dalam kegiatan kelompok itu, anak cenderung asal mengikuti kegiatan sehingga dirasakan kurang merangsang perkembangan anak dalam hal bersosialisasi terutama untuk anak yang memang pada dasarnya pendiam dan jarang bicara. Sehingga penulis akan mencoba menggunakan metode proyek dalam penelitian ini terhadap kemampuan bersosialisasi anak di kelas B1 yang dirasakan perlu di tingkatkan.

2. Ternyata dengan menggunakan metode proyek dengan dilakukan tiga perlakuan/Treatment pada kelas B1 dalam penelitian ini aktivitas bersosialisasi anak dalam kegiatan kelompok melalui proyek ini dirasakan semakin berkembang dengan baik. Perlakuan pertama dilakukan dengan kegiatan menghias rumah adat, perlakuan kedua dilakukan dengan metode proyek langsung ke tempat tukang kayu, perlakuan ketiga dengan kegiatan proyek mempersiapkan acara ulang tahun. Dasar yang diambil oleh peneliti sehingga diberikan tiga perlakuan di kelas B1 dalam penelitian ini, karena untuk meyakinkan peneliti bahwa metode proyek memang benar-benar bisa diterapkan dalam meningkatkan kemampuan bersosialisasi anak usia 5-6 tahun. Terbukti dari saat apresepsi kemudian menentukan rancangan kegiatan proyek, kemudian mengumumkan kegiatan proyek yang akan di laksanakan anak sudah sangat semangat dan termotivasi untuk melaksanakan kegiatan. Hal itu terlihat dari sikap anak dengan penuh semangat terlibat dalam proyek mempersiapkan ulang tahun, sebagian besar anak sudah mampu menyelesaikan tanggung jawabnya secara tuntas dalam proyek, anak-anak sudah mampu mengerjakan tugas mandiri secara kreatif dalam proyek dan anak dapat menyelesaikan bagian pekerjaan bersama anak lain dalam proyek.

3. Terdapat perbedaan yang signifikan terhadap kemampuan perkembangan bersosialisasi anak usia 5-6 tahun pada saat sebelum diterapkannya metode proyek dengan setelah diterapkannya metode proyek dalam kegiatan pembelajaran kelompok yang dilakukan di TK Bina Nusantara. Ada perbedaan nilai yang diperoleh dalam ke tiga perlakuan yang diberikan dalam penelitian ini selama mengunakan metode proyek terhadap kemampuan bersosialisasi anak. Hal ini dapat dilihat dari perolehan nilai rata-rata pada tiap perlakuan yang diberikan, rata-rata nilainya semakin meningkat dari tiap tahap 
tes yang dilakukan, sehingga dapat dengan jelas terlihat bahwa pembelajaran kelompok dengan menggunakan metode proyek sangat berpengaruh secara signifikan terhadap perkembangan kemampuan bersosialisasi pada anak usia 5-6 tahun di TK Bina Nusantara Desa Naluk Kesamatan Cimalaka Kabupaten Sumedang.

Penulis mengemukakan beberapa saran bagi para pembuat kebijakan, kepada para pengguna hasil penelitian ini dan kepada peneliti berikutnya yang berminat untuk melakukan penelitian selanjutnya, antara lain adalah sebagai berikut.

1. Untuk pihak yang senantiasa terkait dalam masalah pendidikan anak usia dini hendaknya membuat suatu kebijakan yang menitik beratkan pada keharusan untuk selalu menerapkan suatu metode/cara/strategi belajar yang tepat dalam setiap kegiatan pembelajaran yang diselenggarakan di Taman Kanak-kanak Karena ternyata metode yang tepat akan sangat berpengaruh terhadap hasil pembelajaran. Seperti halnya penerapan metode proyek melalui kegiatan berkelompok sangatlah tepat digunakan dalam perkembangan sosial anak dan sangat berpengaruh terhadap aspek-aspaek perkembangan anak yang lainnya.

2. Untuk pengguna hasil penelitian ini terutama bagi para guru yang akan menggunakan metode proyek dalam kegiatan pembelajaran hendaklah memperhatikan berbagai aspek yang harus dipenuhi oleh guru, seperti : merancang persiapan yang dilakukan guru, merancang pelaksanaan kegiatan proyek bagi anak, dan merancang penilaian kegiatan proyek bagi anak. Dan ada beberapa faktor yang harus di perhatikan dalam memilih metode proyek yaitu : proyek harus sesuai dengan minat/kebutuhan/pengalaman belajar, harus sesuai dengan kematangan anak, proyek harus merangsang dan memberikan kesempatan kepada siswam untuk berfikir dan berkreasi, proyek harus dikemas dalm sebuah perencanaan yang meliputi tujuan, aktivitas yang akan dilakukan, alat-alat yang digunakan, penilaian dan tindak lanjut dari kegiatan yang sudah dilakukan.

3. Untuk para peneliti lain yang akan melakukan penelitian di bidang yang sama hendaklah lebih menggali lagi masalah-masalah yang diakibatkan oleh penggunaan sebuah metode terhadap pencapaian peningkatan tujuan pembelajaran dan semoga penelitian ini dapat menjadi sumber yang bermanfaat.

\section{DAFTAR PUSTAKA}

Abidin, Y. (2009). Bermain . Bandung: Rizqi Press.

Abidin, Y .(2011). Penelitian Pendidikan Dalam Gamitan Pendidikan Dasar dan PAUD. Bandung: Rizqi Press.

Bahri dan Zain (2006). Strategi Belajar Mengajar. Jakarta: RINEKA CIPTA.

Djaali (2009). Psikologi Pendidikan. Jakarta: BUMI AKSARA.

Dimyati dan Mudjiono. (2006). Belajar dan Pembelajaran. Jakarta: PT. Asdi Mahastya.

Hurlock (2007). Psikologi Perkembangan. Jakarta: Erlangga. 
Kesti (2011). Meningkatkan Kecerdasaan Naturalis Anak Usia Dini Melalui Penggunaan Metode Proyek di Paud Nurul Hikmah. Skripsi Sarjana Pendidikan pada FIP UPI Bandung: tidak diterbitkan.

Lwin, dkk (2008). Cara Mengembangkan Berbagai Komponen Kecerdasan. Jakarta:Indeks.

Masitoh, dkk. (2005). Pendekatan Belajar Aktif di Taman Kanak-kanak. Jakarta: Depdiknas.

Moeslichatoen, (2004). Metode Pengajaran Di Taman Kanak-kanak. Jakarta: Rineka Cipta dan Depdikbud.

Mutiara (2011). Peningkatan Kecerdasan Emosional Anak Usia Dini Melalui Metode Proyek di Kober Tridaya Kelas A (Lemon). Skripsi Sarjana Pendidikan pada FIP UPI Bandung: tidak diterbitkan.

Nugraha, dkk. (2009). Program Pelibatan Orang Tua dan Masyarakat. Jakarta: Universitas Terbuka.

Nurmalasari (2010). Meningkatkan Kecerdasan Interpersonal Anak Taman Kanak-kanak Melalui Penerapan Metode Proyek. Skripsi Sarjana Pendidikan pada FIP UPI Bandung: tidak diterbitkan.

Sanjaya, Wina. (2008). Strategi Pembelajaran Berorientasi Standar Proses Pendidikan.Jakarta: Kencana Prenada Media Group.

Solehuddin, M. (1997). Konsep Dasar Pendidikan Prasekolah. Bandung: FIP UPI Sudjana, (2005).Metoda Statistika. Bandung: Tarsito.

Sugiyono. (2010). Metode Penelitian Kuantitatif, Kualitatif dan R\&D. Bandung: Alfabeta.

Yamin, Martinis , (2010). Desain Pembelajaran Berbasis Tingkat Satuan Pendidikan. Jakarta: Gaung Persada Press.

Yusuf, Syamsu. (2006). Psikologi Perkembangan Anak dan Remaja. Bandung: PT. Remaja Rosdakarya. 